M.O. Chaban, L.M. Rozhdestvenska, O.V. Palchik

\title{
SORPTION REMOVAL OF $\mathrm{Li}^{+}$IONS FROM MULTICOMPONENT SOLUTIONS. REGENERATION OF SORBENT AND PROCESSING OF CONCENTRATE
}

\author{
V.I. Vernadsky Institute of General and Inorganic Chemistry of the National Academy of Sciences of \\ Ukraine, Kyiv, Ukraine
}

\begin{abstract}
The work is devoted to the development of a sorption method for the extraction of lithium from seawater using oxides of polyvalent metals obtained in the form of large granules. The initial oxides of $\mathrm{Ti}$ and $\mathrm{Ti}-\mathrm{Mn}$ contained a phase of lithium spinel, the sorbents were previously converted into hydrogen form. Sorption of $\mathrm{Li}^{+}$ions under dynamic conditions was investigated using a model solution containing the following alkali metal ions $\left(\mathrm{mmol} \cdot \mathrm{dm}^{-3}\right)$ : $\mathrm{Li}^{+}$0.014, $\mathrm{Na}^{+}$252.1, and $\mathrm{K}^{+}$5.4. The ratio of $\mathrm{Li}^{+}, \mathrm{Na}^{+}$and $\mathrm{K}^{+}$contents in the sorbents was found to be 1:11:1 (in $\mathrm{TiO}_{2}$ ) and 1:4:1 (in Ti-Mn), respectively. These sorbents could be regenerated by $\mathrm{NaOH}$ solution (partially) or by acids (completely); they did not dissolve in $1 \mathrm{M} \mathrm{HNO}_{3}$ at $20-45^{\circ} \mathrm{C}$. The effects of sorbent dosage and concentration of $\mathrm{HNO}_{3}$ solution on desorption of $\mathrm{Li}^{+}$ions were studied. Several cycles of sorption-desorption were carried out for titanium-manganese sorbent without renewal of the regenerating solution. It was shown that the sorption capacity remains constant for 5 cycles; then it is decreased and can be recovered by using a fresh regenerating solution. The treatment of the obtained concentrate involves bubbling ammonia through the solution, precipitation of $\mathrm{LiCO}_{3}$ and formation of a mixture of nitrates and carbonates of potassium and sodium that can be further used as fertilizer. It is proposed to integrate the lithium extraction into the reverse osmotic desalination of seawater: the sorption process implies its preliminary softening.
\end{abstract}

Keywords: lithium, titanium-manganese spinel, seawater desalination, sorption, sorbent regeneration.

DOI: $10.32434 / 0321-4095-2020-131-4-177-186$

\section{Introduction}

Lithium and its compounds are used to produce alloys, thermoelectric, optical and laser materials as well as in medicine, metallurgy and pyrotechnics [1]. Currently, the focus is on lithium use in chemical sources of current: anodes are made from lithium [2]. This metal is a part of the compounds used as liquid and solid electrolytes of lithium-ion batteries. The annual increase in lithium production in the world is driven by the rapid development of alternative energy: the demand for this metal in 2020 is projected to be 20,000 tonnes in terms of lithium carbonate [3]. The sources of lithium are waters from salt lakes and mineral resources, for example, spodumene, petalite, and amblygonite [4]. Solar evaporation, extraction, coprecipitation, and membrane processes are used for the production of lithium from brines and salt lakes [5]. Mineral deposits and natural brines are depleted over time, and the exploitation of such deposits has a negative impact on the environment. Seawater is considered as an alternative source of lithium, which, in contrast to the above, contains a much smaller amount of it $\left(0.1-0.2 \mathrm{mg} \cdot \mathrm{dm}^{-3}\right)$ [6]. In this case, the use of adsorption and ion exchange methods is the most appropriate [7-9]. A combination of adsorption and electrodialysis has also been proposed: during the latter, $\mathrm{Li}^{+}$ions accumulate in the adsorbent [10]. After stopping the process for washing of the membrane system, the adsorbent is regenerated, and the eluate is subsequently used to precipitate lithium carbonate.

Among the adsorption materials, inorganic ones are the most attractive; they are used to modify membranes [11] and ion exchange resins [12] in order to impart increased selectivity to them. It is known 
that adsorbents based on lithium titanates and manganites are selective with respect to the ions of this metal $[7-9,13]$. These materials are fabricated by environmentally friendly methods using affordable and inexpensive raw materials, their synthesis is not a laborious procedure. Previously, we obtained titanium-manganese adsorbents, which, unlike the known ones, were characterized by a large granule size (several hundred micrometers). However, the regeneration of adsorbents requires the use of acids, since dissolution is possible in acidic media; the intensity of the dissolution depends on the Ti:Mn ratio [14]. The purpose of this work was to establish the optimum conditions for the regeneration of adsorbents to ensure their repeated use. The work also solved the problem of complex processing of the effluent.

\section{Experimental}

Sorbents based on titanium and manganese oxides were synthesized according to the procedure described elsewhere $[9,10]$. Briefly, Ti(IV) was preconverted into citrate complexes by mixing $1 \mathrm{M}$ aqueous $\mathrm{TiCl}_{4}$ solution and $3 \mathrm{M}$ citric acid solution. The hydrogel was precipitated by $1 \mathrm{M} \mathrm{NH}_{4} \mathrm{OH}$ solution. Titanium-manganese sorbent was obtained by mixing $1 \mathrm{M}$ solutions of $\mathrm{TiCl}_{4}$ and $\mathrm{KMnO}_{4}$, the interaction between these components was as follows:

$2 \mathrm{TiCl}_{4}+2 \mathrm{KMnO}_{4}+2 \mathrm{H}_{2} \mathrm{O} \rightarrow$

$\rightarrow 2 \mathrm{TiO}_{2}+2 \mathrm{MnO}_{2}+2 \mathrm{KCl}+2 \mathrm{H}_{2} \mathrm{O}+3 \mathrm{Cl}_{2}$.

The precipitated sorbents were washed with water to $\mathrm{pH} 7$, followed by azeotropic drying using benzene (boiling point was $80^{\circ} \mathrm{C}$ ). The dried sorbents were kept in $1 \mathrm{M} \mathrm{LiOH}$ solution, washed with deionized water from excess alkali, and calcined at $600^{\circ} \mathrm{C}$. For sorbents prepared at this temperature, the optimum combination of sorption rate and selectivity for $\mathrm{Li}^{+}$ions is achieved $[9,10]$. Then, the sorbents were washed sequentially with $1 \mathrm{M} \mathrm{HNO}_{3}$ from lithium and with deionized water from acid to $\mathrm{pH} \mathrm{7,} \mathrm{and} \mathrm{dried} \mathrm{at} \mathrm{room} \mathrm{temperature} \mathrm{to} \mathrm{a} \mathrm{constant}$ weight. The fraction of $0.25-0.50 \mathrm{~mm}$ was selected.

The effect of the reagent on the desorption of $\mathrm{Li}^{+}$was studied in the following way. A portion of the sorbent $(1 \mathrm{~g})$ was kept in a $0.1 \mathrm{M} \mathrm{LiCl}$ solution $\left(100 \mathrm{~cm}^{3}\right)$ for $48 \mathrm{~h}$ (static sorption). Then, the sorbent was washed with water from excess $\mathrm{Li}^{+}$ions for $3 \mathrm{~h}$ (control was performed by ionomer I-160 MI equipped with $\mathrm{Li}$-selective electrode ЕЛIC-142Li). The solid phase was separated from the liquid, and $100 \mathrm{~cm}^{3}$ of $1 \mathrm{M} \mathrm{HNO}_{3}$ solution was added to the tank with the sorbent. Desorption was carried out with vigorous stirring by shaking containers containing sorbent and solution. After $48 \mathrm{~h}$, the eluate was analyzed using a Pye Unicam 8800 atomic absorption spectrometer (Philips). To establish the value of the sorption capacity after transfer to the lithium form, the sorbents were recovered by $3 \mathrm{M}$ $\mathrm{HNO}_{3}$ solution. The absence of $\mathrm{Li}^{+}$ions in the eluate indicated the completeness of regeneration with exactly $1 \mathrm{M}$ acid solution.

The sorption capacity was calculated by the following formula

$\mathrm{A}=\frac{\mathrm{CV}}{\mathrm{m}}$

where $\mathrm{C}$ is the concentration of the eluate, $\mathrm{V}$ is its volume, and $\mathrm{m}$ is the weight of the sample.

The degree of regeneration (RD) was defined as $\frac{A_{0}-A}{A_{0}}$. Here, $A_{0}$ is the initial capacity of the sorbent.

Deionized water, $1 \mathrm{M} \mathrm{H}_{2} \mathrm{SO}_{4}, \mathrm{HCl}$ and $\mathrm{NaOH}$ solutions were also used for regeneration. Acid eluates were also analyzed for titanium content (spectrophotometric method using $\mathrm{H}_{2} \mathrm{O}_{2}$ ) and manganese (atomic absorption method). The sorbents were regenerated with acids both at $25^{\circ} \mathrm{C}$ and at $45^{\circ} \mathrm{C}$.

The dosage of titanium-manganese sorbent saturated with $\mathrm{Li}^{+}$ions was also varied. Thus, the effect of the amount of sorbent on the rate of sorption was investigated. The ratios of the masses of the solution and the sorbent were 2, 5, 10, 50 and 100 . Accordingly, the dosages of the sorbent were 500, 200, 100, 20 and $10 \mathrm{~g} \cdot \mathrm{dm}^{-3} .1 \mathrm{M} \mathrm{HNO}_{3}$ solution was used and desorption was carried out at the temperature of $25^{\circ} \mathrm{C}$. The samples $\left(1 \mathrm{~cm}^{3}\right)$ were periodically taken from the solution, then diluted 15 times and analyzed. After $48 \mathrm{~h}$, the liquid phase was separated from the solid. In the case of large doses of sorbent $\left(500,200\right.$ and $\left.100 \mathrm{~g} \cdot \mathrm{dm}^{-3}\right)$, the eluate was diluted 10 -fold and titrated by $0.1 \mathrm{M} \mathrm{NaOH}$ solution in the presence of phenolphthalein indicator.

To study the desorption of titanium-manganese sorbent, solutions of $\mathrm{HNO}_{3}$ of different concentrations were also used, the dosage being $10 \mathrm{~g} \cdot \mathrm{dm}^{-3}$ in this case. The desorption duration was 72 hours and 48 hours for acid concentration of $0.1 \mathrm{M}$ and for other concentrations, respectively.

For the implementation of multiple sorptionregeneration model, three-component solution was used which contained $\left(\mathrm{mmol} \cdot \mathrm{dm}^{-3}\right)$ : $\mathrm{Li}^{+} 0.014, \mathrm{Na}^{+}$ 252.1, and $\mathrm{K}^{+}$5.4. The content of alkali metals in this solution corresponded to their concentration in 
the Black Sea water [10]. The sorption was carried out in dynamic mode: the column diameter was $1.3 \mathrm{~cm}$ and the height of the sorbent layer (titaniummanganese or $\mathrm{TiO}_{2}$-based) was $42 \mathrm{~cm}$. The solution was passed through the column in direct-flow mode. Transfusion was stopped when the $\mathrm{pH}$ and concentration of $\mathrm{Li}^{+}$in the outlet solution ceased to change. The sorbent capacity was calculated as $\frac{\left(\mathrm{C}_{\text {inl }}-\mathrm{C}_{\text {outl }}\right)}{\mathrm{m}}$ where $\mathrm{C}_{\text {inl }}$ and $\mathrm{C}_{\text {outl }}$ are the concentrations at the inlet and outlet of the column, respectively.

Thereafter, a fivefold volume of $1 \mathrm{M} \mathrm{HNO}_{3}$ solution was circulating through a column for $30 \mathrm{~h}$. The eluate was used to further regenerate the sorbent after the next sorption cycle. The column was then washed with deionized water in a flow-through mode. The $\mathrm{pH}$ of the solution at the outlet of the column and the content of the $\mathrm{NO}_{3}{ }^{-}$anions were monitored (with the help of the ЕЛІC-121 $\mathrm{NO}_{3}$ ion selective electrode). The number of regeneration sorption cycles was 1 and $7\left(\mathrm{TiO}_{2}\right.$-based sorbent and titanium manganese sorbent, respectively). After seven cycles, the sorbent was washed with freshly prepared $1 \mathrm{M}$ $\mathrm{HNO}_{3}$ solution (a fivefold volume) and deionized water; and the sorption-regeneration was performed again.

To process the eluate $\left(\approx 1 \mathrm{dm}^{3}\right)$, the solution was neutralized by ammonia bubbling, then evaporated to $25 \mathrm{~cm}^{3}$ in a water bath, the temperature of which excided $60^{\circ} \mathrm{C}$. Lithium carbonate was precipitated by saturated $\mathrm{K}_{2} \mathrm{CO}_{3}$ solution at room temperature. The precipitate was washed with hot water at the temperature approaching $100^{\circ} \mathrm{C}$.

\section{Results and discussion}

As previously established by using thermogravimetric and $\mathrm{X}$-ray phase analysis, a material containing crystalline polymorphic $\mathrm{TiO}_{2}$ (70\%) and spinel $\mathrm{Li}_{4} \mathrm{Ti}_{5} \mathrm{O}_{12}$ (30\%) is formed during calcination of hydrated titanium dioxide saturated with $\mathrm{LiOH}$ in the temperature range of $500-700^{\circ} \mathrm{C}$. In the case of mixed oxide, crystallization results in two phases: rutile $(60 \%)$ and spinel $\mathrm{Li}_{0.75} \mathrm{Mn}_{0.25} \mathrm{Ti}_{2} \mathrm{O}_{4}$ (40\%) [9]. In the treatment of calcined samples with acid, the $\mathrm{Li}^{+}$ions are removed and the samples are converted into the hydrogen form. Such materials are capable of absorbing $\mathrm{Li}^{+}$ions. As noted in ref. [10], spinel provides the selectivity of sorption of $\mathrm{Li}^{+}$ions due to their intercalation between octahedra and ensures electrical neutrality due to the adsorption of anions in the spaces between the spinel and rutile nanocrystals. Not only $\mathrm{Li}^{+}$ions but also other cations present in the solution are adsorbed on the surface of the nanocrystals. This factor reduces the selectivity of the sorbent. Additionally, titanium oxides act as a binder that prevents fragmentation of the granules. The developed approach to synthesis allowed obtaining materials with high selectivity with respect to $\mathrm{Li}^{+}$ions, which, unlike the known ones, are characterized by a sufficiently large size of granules. The possibility of using a sorbent as a filler of the electrodialysis cell for the desalination of seawater was considered earlier: in this case, sorption occurs directly from the concentrate and the desorption of $\mathrm{Li}^{+}$is carried out during the regeneration of the membrane system [10]. Thus, the lithium-containing eluate formed during sorbent regeneration is a byproduct of electrodialysis desalination of seawater. The large size of the granules makes it impossible to lose the sorbent due to its removal from the electrodialysis cell by the flow of solution.

These granules are splices of particles larger than $100 \mathrm{~nm}$ in size (Fig. 1,a). Therefore, the surface of the granules is embossed. As previously established by the X-ray phase analysis and transmission electron microscopy, such particles consist of nanocrystallites 9-34 nm in size [9]. The specific surface area of the sample based on $\mathrm{TiO}_{2}$ is $90 \mathrm{~m}^{2} \cdot \mathrm{g}^{-1}$. However, despite the small surface area, the saturation of the sorbent with $\mathrm{Li}^{+}$ions ensures the capacity of $0.16 \mathrm{mmol} \cdot \mathrm{g}^{-1}$ in the neutral region due to intercalation. The surface of the titanium-manganese sorbent is $86 \mathrm{~m}^{2} \cdot \mathrm{g}^{-1}$ and the sorption capacity is $0.4 \mathrm{mmol} \cdot \mathrm{g}^{-1}$ in a neutral medium.

It is established that the sorbent regeneration is complete when interacted with $1 \mathrm{M}$ acid solutions. When treated with deionized water, the degree of regeneration (RD) is only $1-2 \%$, which is caused by the removal of the non-adsorbed $\mathrm{Li}^{+}$ions from the narrow pores (these ions were not removed when washing the Li-shaped samples). Ion exchange occurs during the treatment of samples with alkali:

$-\mathrm{O}^{-} \mathrm{Li}^{+}{ }_{\text {solid }}+\mathrm{Na}^{+}{ }_{\text {aq }} \rightarrow-\mathrm{O}^{-} \mathrm{Na}^{+}{ }_{\text {solid }}+\mathrm{Li}^{+}{ }_{\text {aq }}$,

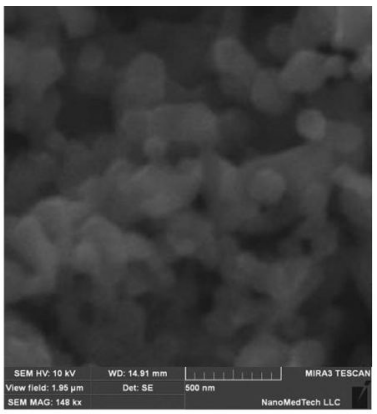

a

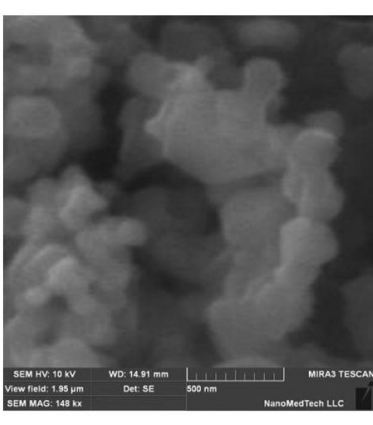

b
Fig. 1. SEM images of titanium-manganese sorbent before (a) and after (b) 10 cycles of sorption-regeneration 
and acid:

$-\mathrm{O}^{-} \mathrm{Li}^{+}{ }_{\text {solid }}+2 \mathrm{H}^{+}{ }_{\mathrm{aq}} \rightarrow-\mathrm{OH}_{2}{ }_{\text {solid }}+\mathrm{Li}^{+}{ }_{\text {aq }}$.

Desorption may also involve the destruction of non-dissociated $-\mathrm{OLi}$ ion pairs. In the environment of acids Han, regeneration also includes deintercalation of $\mathrm{Li}^{+}$as follows:

$$
\begin{aligned}
& \mathrm{Li}^{+}{ }_{\text {solid }}+\mathrm{Cl}^{-}{ }_{\text {solid }}+\mathrm{H}^{+}{ }_{\text {aq }}+\mathrm{An}^{-}{ }_{\text {aq }} \rightarrow \\
& \rightarrow \mathrm{Li}^{+}{ }_{\text {aq }}+\mathrm{Cl}^{-}{ }_{\text {aq }}+\mathrm{H}^{+}{ }_{\text {solid }}+\mathrm{An}^{-} \text {solid. }
\end{aligned}
$$

In an alkaline medium, the exchange of $\mathrm{Na}^{+} \rightarrow \mathrm{Li}^{+}$results in a $40 \%$ degree of desorption in the case of $\mathrm{TiO}_{2}$-based sorbent. In the case of titanium-manganese sorbent with less spinel content, $\mathrm{RD}=30 \%$. Under the action of acids, complete desorption of $\mathrm{Li}^{+}$is achieved. However, titanium ( $\mathrm{TiO}_{2}$-based sorbent regeneration) was found in sulfuric acid: its concentration was $0.1 \mathrm{mg} \cdot \mathrm{dm}^{-3}$ (at $20^{\circ} \mathrm{C}$ ) and $0.2 \mathrm{mg} \cdot \mathrm{dm}^{-3}$ (at $45^{\circ} \mathrm{C}$ ). These losses correspond to 0.001 and 0.002 wt.\%. For titaniummanganese sorbent, it was found that the losses of manganese at $20^{\circ} \mathrm{C}$ were $0.005-0.007 \mathrm{wt} . \%$ and $0.01-$ 0.014 wt.\% in $\mathrm{HCl}$ and $\mathrm{H}_{2} \mathrm{SO}_{4}$ media, respectively. From a formal point of view, spinning of manganese from spinel can be represented by the following scheme [14]:

$2 \mathrm{LiMn}_{2-\mathrm{y}} \mathrm{Ti}_{\mathrm{y}} \mathrm{O}_{4}$, solid $\rightarrow$ $\rightarrow 2 \mathrm{Li}^{+}{ }_{\mathrm{aq}}+\mathrm{Mn}^{2+}{ }_{\mathrm{aq}}+3 / 2\left(\mathrm{Mn}_{2(3-2 \mathrm{y}) / 3} \mathrm{Ti}_{4 \mathrm{y} / 3} \mathrm{O}_{4}\right)_{\text {solid }}$.

Recovery of manganese (IV) is accompanied by the release of oxygen in $\mathrm{H}_{2} \mathrm{SO}_{4}$ or chlorine $(\mathrm{HCl})$ media. The intensity of these processes increases with

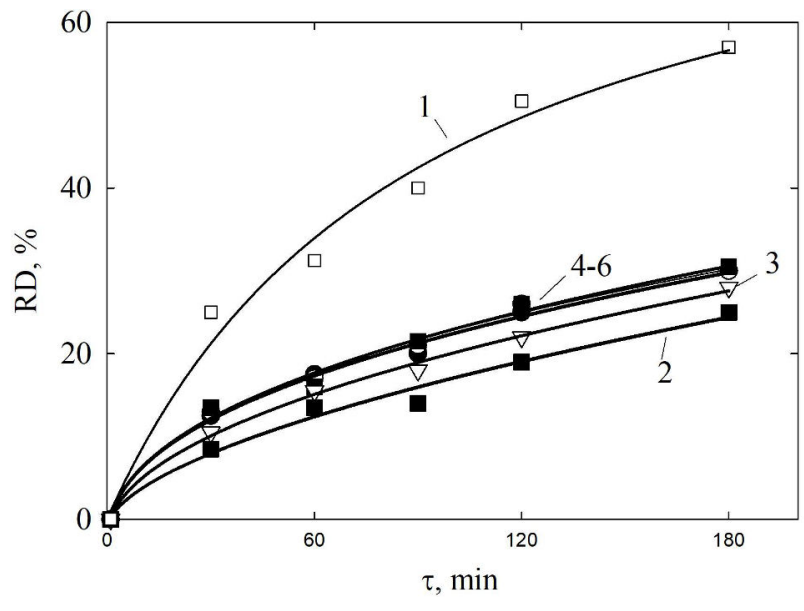

a increasing the temperature and concentration of acids. However, no manganese was found in nitric acid. This acid was subsequently used for regeneration. Since complex processing of the eluate involves not only the production of lithium compounds but also the utilization of the solution, nitric acid looks more attractive, since the solution containing $\mathrm{NO}^{3-}$ anions can be used to produce mineral fertilizers.

As can be seen from Fig. 2,a, the highest desorption rate is characteristic to manganese-free oxide (for the sake of clarity, only the initial sections of the curves in the range of $\tau<3 \mathrm{~h}$ are shown). The titanium-manganese sorbent exhibits lower rate of desorption, which is obviously due to not only exchange according scheme shown by Eq. (4) but also deintercalation of $\mathrm{Li}^{+}$Eq. (5). The dosage of sorbent of $10-100 \mathrm{~g} \cdot \mathrm{dm}^{-3}$ does not practically affect the rate of desorption, and a further increase in the amount of sorbent inhibits desorption.

The mechanism of deintercalation is indirectly confirmed by the fact that A vs. $\tau$ dependences are in compliance with the pseudo-first order chemical reaction equation (Fig. 2,b). This equation can be written as follows:

$$
\ln \left(A_{0}-A\right)=\ln A_{0}-k_{1} \tau
$$

were $A_{0}$ is the output capacity of the sorbent. The values of the constants are given in Table 1. A good fit of the experimental and calculated data as well as a high correlation coefficient (97-98\%) confirms the correctness of the selected model. The time required to reach $\mathrm{RD}=99 \%$ (in this case $\mathrm{A}=0.99 \mathrm{~A}_{0}$ ) is determined by the formula:

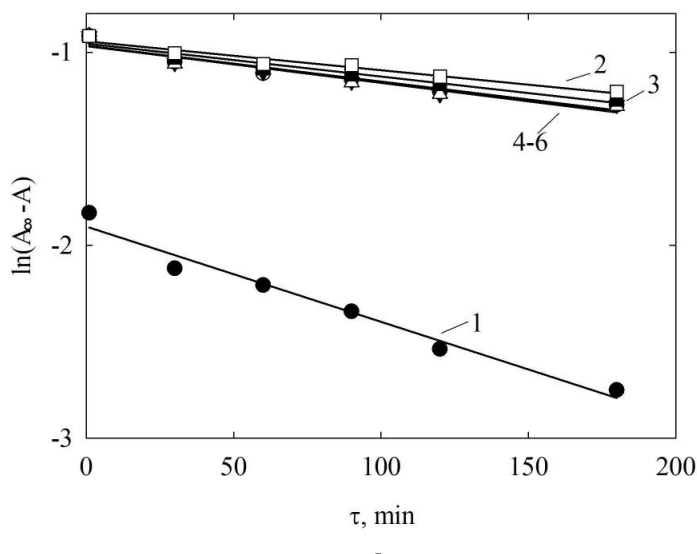

b

Fig. 2. Dependence of the regeneration degree of sorbents based on $\mathrm{TiO}_{2}(1)$ and $\mathrm{TiO}_{2}-\mathrm{MnO}_{2}$ (2)-(6) on time (a), and application of the pseudo-first order desorption model (b). Reagent: $1 \mathrm{M}$ solution of $\mathrm{HNO}_{3}$, dosage of sorbent $\left(\mathrm{g} \cdot \mathrm{dm}^{-3}\right)$ : $10-(1)$ and (6), $20-(5), 100-(4), 200-(3)$, and $1000-(2)$ 
Modeling of $\mathrm{Li}^{+}$desorption kinetic curves according to the pseudo-first order kinetic equation

\begin{tabular}{|c|c|c|c|c|c|c|}
\hline \multirow{2}{*}{ Adsorbent } & \multirow{2}{*}{$\begin{array}{l}\text { Dosage, } \\
\mathrm{cm}^{3} \cdot \mathrm{dm}^{-3}\end{array}$} & \multirow{2}{*}{$\begin{array}{c}\text { Concentration } \\
\text { of } \mathrm{HNO}_{3}, \mathrm{M}\end{array}$} & \multirow{2}{*}{$\begin{array}{c}\mathrm{k} \cdot 10^{5} \\
\mathrm{~s}^{-1}\end{array}$} & \multicolumn{2}{|c|}{$\mathrm{A}, \mathrm{mmol} \cdot \mathrm{g}^{-1}$} & \multirow{2}{*}{$\begin{array}{c}\tau, \mathrm{h} \\
\text { (calculated for } \mathrm{RD}=99 \% \text { ) }\end{array}$} \\
\hline & & & & experimental & calculated & \\
\hline $\mathrm{TiO}_{2}$ & 10 & 1.0 & 8.21 & 0.16 & 0.15 & 16 \\
\hline $\mathrm{TiO}_{2}-\mathrm{MnO}_{2}$ & 10 & 1.0 & 3.18 & 0.4 & 0.38 & 40 \\
\hline $\mathrm{TiO}_{2}-\mathrm{MnO}_{2}$ & 20 & 1.0 & 3.13 & 0.4 & 0.38 & 41 \\
\hline $\mathrm{TiO}_{2}-\mathrm{MnO}_{2}$ & 100 & 1.0 & 3.10 & 0.4 & 0.38 & 41 \\
\hline $\mathrm{TiO}_{2}-\mathrm{MnO}_{2}$ & 200 & 1.0 & 2.85 & 0.4 & 0.39 & 45 \\
\hline $\mathrm{TiO}_{2}-\mathrm{MnO}_{2}$ & 500 & 1.0 & 2.50 & 0.4 & 0.39 & 51 \\
\hline $\mathrm{TiO}_{2}-\mathrm{MnO}_{2}$ & 10 & 0.1 & 1.67 & 0.4 & 0.39 & 76 \\
\hline $\mathrm{TiO}_{2}-\mathrm{MnO}_{2}$ & 10 & 0.2 & 2.23 & 0.4 & 0.39 & 55 \\
\hline $\mathrm{TiO}_{2}-\mathrm{MnO}_{2}$ & 10 & 2.0 & 2.88 & 0.4 & 0.38 & 44 \\
\hline $\mathrm{TiO}_{2}-\mathrm{MnO}_{2}$ & 10 & 3.0 & 3.18 & 0.4 & 0.38 & 40 \\
\hline
\end{tabular}

$$
\tau=-\frac{\ln 0.001}{\mathrm{k}_{1}}=\frac{4.6}{\mathrm{k}_{1}}
$$

Thus, the full desorption time is $16 \mathrm{~h}$ and $40-$ $50 \mathrm{~h}$ for $\mathrm{TiO}_{2}$-based sorbent and titanium-manganese sorbent, respectively. Thus, the selected desorption time (48 hours) is sufficient for complete regeneration of the sorbent. The constant of desorption rate is less by $\sim 2-9$ times than amorphous non-calcined adsorbent (hydrated zirconium dioxide) [15]. In the case of zirconium-containing adsorbent, desorption of large uranyl ions was studied.

A decrease in the rate of desorption with increasing dosage of the sorbent is probably due to a decrease in acid concentration. If the dosage of the sorbent is $500 \mathrm{~g} \cdot \mathrm{dm}^{-3}, 0.8 \mathrm{~mol}$ of acid contained in $2 \mathrm{dm}^{-3}$ is consumed for the regeneration of $1 \mathrm{~kg}$ of sorbent. Thus, the final $\mathrm{HNO}_{3}$ concentration will be $0.6 \mathrm{M}$. It is established by titration that the final

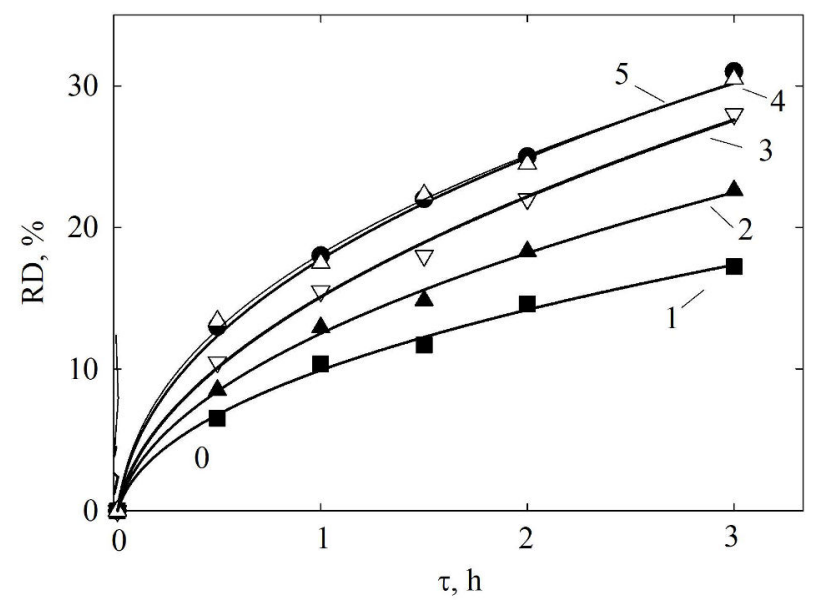

a

Fig. 3. The degree of desorption of $\mathrm{Li}^{+}$from titanium-manganese sorbent as a function of time. The concentration of $\mathrm{HNO}_{3}$

solution was $0.1 \mathrm{M}(1), 0.2 \mathrm{M}(2), 1 \mathrm{M}(3), 2 \mathrm{M}(4)$, and 3 M (5)
$\mathrm{HNO}_{3}$ concentration corresponds to $0.57 \mathrm{M}$ and this value is close to the calculated one. For a dosage of $200 \mathrm{~g} \cdot \mathrm{dm}^{-3}$, the experimental value of the final acid concentration reaches $0.81 \mathrm{M}$ (the calculated value is $0.84 \mathrm{M}$ ). For a dosage of $100 \mathrm{~g} \cdot \mathrm{dm}^{-3}$, the experimental value is $0.9 \mathrm{M}$ (the calculated value is $0.92 \mathrm{M})$.

A decrease in the concentration of $\mathrm{HNO}_{3}$ inhibits desorption (Fig. 3). It is found that the kinetic curves A vs. $\tau$ also obey the pseudo-first order kinetic equation. As can be seen from Table 1, a decrease in the acid concentration leads to slower desorption. In the case of the initial acid concentration of $0.1 \mathrm{M}$, its final concentration was $0.094 \mathrm{M}$ (the calculated value was $0.096 \mathrm{M}$ ). It should be noted that some fragmentation of the sorbent granules occurs when the concentration of acid exceeds $1 \mathrm{M}$ : the presence of the sorbent fraction $<0.16 \mathrm{~mm}(\sim 10-$ $15 \%)$ was detected after regeneration. Thus, it is advisable to use a $1 \mathrm{M}$ solution of $\mathrm{HNO}_{3}$ for multiple

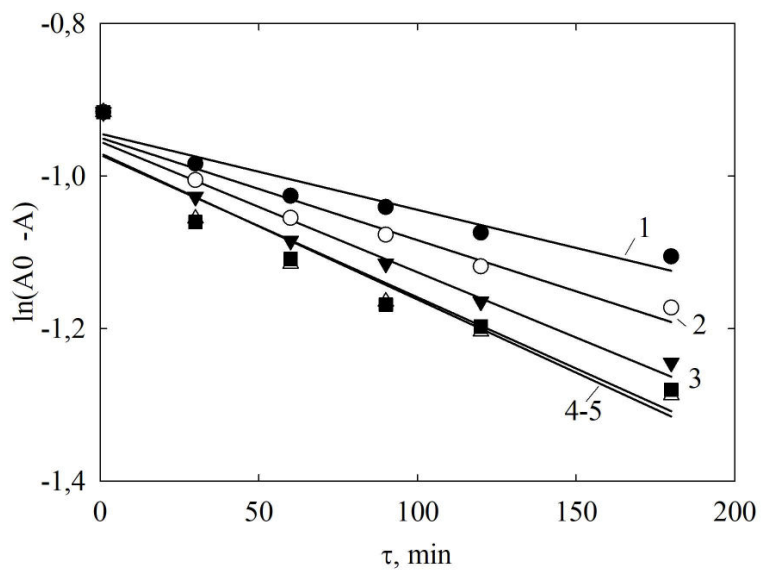

b

Sorption removal of $\mathrm{Li}^{+}$ions from multicomponent solutions. Regeneration of sorbent and processing of concentrate 
regeneration. To prevent the formation of large volume of the eluate, the recommended dosage of sorbent is $200 \mathrm{~g} \cdot \mathrm{dm}^{-3}$. At the same time, a regeneration rate of $\sim 95 \%$ is achieved for 30 hours according to our calculations.

It should be noted that prolonged contact with nitric acid solution does not change the morphology of titanium-manganese sorbent (Fig. 1).

To study the sorption of $\mathrm{Li}^{+}$from a multicomponent solution, a model solution was used, the composition of which, with respect to alkali metal ions, corresponded to seawater, from which the ions were removed. The results of the study of multiple sorption-regeneration are given in Table 2. The following sorption capacity values were obtained in case of $\mathrm{TiO}_{2}$ for the first sorption cycle $\left(\mathrm{A}_{1}, \mathrm{mmol} \cdot \mathrm{g}^{-1}\right)$ : $\mathrm{Li}^{+} 0.012, \mathrm{Na}^{+} 0.14$, and $\mathrm{K}^{+} 0.012$. In case of titanium-manganese sorbent, the respective values were as follows: $\mathrm{Li}^{+} 0.063, \mathrm{Na}^{+} 0.27$, and $\mathrm{K}^{+} 0.065$. After each cycle, the losses of the regenerating solution were $0.2 \mathrm{~V}_{\mathrm{s}}$ (where $\mathrm{V}_{\mathrm{s}}$ is the volume of the sorbent, which was $223 \mathrm{~cm}^{3}$ ). Therefore, the volume of the regenerating solution was $3.8 \mathrm{~V}_{\mathrm{s}}$ after the seventh cycle. As can be seen from Table 2, the concentration of alkali metal ions in the eluate increased after each cycle of sorption-desorption. After 5 cycles, a decrease in the degree of desorption was observed, which indicates a shift of the sorption equilibrium towards the formation of the substituted sorbent form.

In addition, the deterioration of regeneration is due to the depletion of the acid solution, which is spent on the $\mathrm{H}^{+} \rightarrow \mathrm{Li}^{+}$exchange. It is worth noting that, the concentration of $\mathrm{Li}^{+}$ions in the eluate is $0.01 \%$ after 5 cycles, which corresponds to the lithium content of the solution formed by the evaporation of water of some Chile salt lakes. Given that in seawater the content of $\mathrm{Li}^{+}$ions is $0.014 \mathrm{mmol} \cdot \mathrm{m}^{-3}$, the sorption method allows concentrating it more than by 1000 times. The ratio of $\mathrm{Na}^{+}$to $\mathrm{Li}^{+}$concentrations in seawater reaches 18,000 , while it is $\sim 4$ in the eluate. A similar ratio for $\mathrm{K}^{+}$to $\mathrm{Li}^{+}$ions is 357 (in seawater) and $\sim 1$ (in salt concentrate).

After the seventh cycle, the sorbent was again regenerated with a freshly prepared $1 \mathrm{M} \mathrm{HNO}_{3}$ solution containing no alkali metal ions. It was found that the material restored its sorption properties: the capacity with respect to each ion corresponded to the value of $\mathrm{A}$, which was observed after the first cycle. As the absorption capacity of the sorbent deteriorates during the sixth and seventh cycles (reduction of sorption by $30 \%$ ), a further use of the salt concentrate as a regenerating solution is impractical. Hence, it is recommended to wash the sorbent with a freshly prepared acid solution. Subsequently, the formed eluate can be used in a series of subsequent cycles of sorption-desorption.

Titanium-manganese sorbent exhibits a higher capacity with respect to $\mathrm{Li}^{+}$ions than $\mathrm{TiO}_{2}$-based sorbent. Therefore, double oxide should be used to remove lithium from seawater.

Let us consider the washing of the sorbent with deionized water. Figure 4 illustrates the changes in $\mathrm{pH}$ of the column outlet solution and the concentration of $\mathrm{NO}_{3}{ }^{-}$ions. A low $\mathrm{pH}$ at the beginning of washing is due to the removal of acid from the cavities between the grains and macropores of the sorbent. During washing, the $\mathrm{pH}$ of the resulting solution was naturally increased and the content of nitrate ions decreased. It was found that the total concentration of $\mathrm{NO}_{3}^{-}$in the first 5 volumes

Table 2

Sorption of alkali metal ions and sorbent regeneration

\begin{tabular}{|c|c|c|c|c|c|c|c|c|c|}
\hline \multirow{3}{*}{ Cycle } & \multirow{2}{*}{\multicolumn{3}{|c|}{ Sorption, $\mathrm{A} / \mathrm{A}_{1}, \mathrm{mmol} \cdot \mathrm{g}^{-1}$}} & \multicolumn{6}{|c|}{ Desorption } \\
\hline & & & & \multicolumn{3}{|c|}{$\mathrm{A}, \mathrm{mmol} \cdot \mathrm{g}^{-1}$} & \multicolumn{3}{|c|}{ Solution concentration, $\mathrm{mmol} \cdot \mathrm{dm}^{-3}$} \\
\hline & $\mathrm{Li}^{+}$ & $\mathrm{Na}^{+}$ & $\mathrm{K}^{+}$ & $\mathrm{Li}^{+}$ & $\mathrm{Na}^{+}$ & $\mathrm{K}^{+}$ & $\mathrm{Li}^{+}$ & $\mathrm{Na}^{+}$ & $\mathrm{K}^{+}$ \\
\hline \multicolumn{10}{|c|}{$\mathrm{TiO}_{2}$ based sorbent } \\
\hline 1 & 1 & 1 & 1 & 0 & 0 & 0 & 0.5 & 6.2 & 0.5 \\
\hline \multicolumn{10}{|c|}{$\mathrm{TiO}_{2}-\mathrm{MnO}_{2}$ based sorbent } \\
\hline 1 & 1.00 & 1.00 & 1.00 & 0.003 & 0.01 & 0.001 & 2.6 & 11.6 & 2.6 \\
\hline 2 & 1.03 & 0.96 & 1.03 & 0.001 & 0.01 & 0.001 & 5.4 & 23.2 & 5.5 \\
\hline 3 & 1.03 & 0.85 & 1.00 & 0.002 & 0.02 & 0.001 & 8.5 & 34.0 & 7.5 \\
\hline 4 & 1.02 & 1.00 & 0.97 & 0.002 & 0.02 & 0.001 & 11.7 & 46.7 & 10.7 \\
\hline 5 & 0.98 & 0.96 & 0.92 & 0.001 & 0.02 & 0.001 & 15.0 & 60.5 & 14.1 \\
\hline 6 & 0.87 & 0.81 & 0.80 & 0.005 & 0.07 & 0.006 & 18.0 & 68.5 & 17.0 \\
\hline 7 & 0.71 & 0.70 & 0.68 & 0.010 & 0.11 & 0.009 & 20.5 & 74.3 & 19.4 \\
\hline \multicolumn{10}{|c|}{$\mathrm{TiO}_{2}-\mathrm{MnO}_{2}$ based sorbent after washing with freshly prepared $\mathrm{HNO}_{3}$ solution } \\
\hline 1 & 1.02 & 0.96 & 0.99 & 0.002 & 0.01 & 0.001 & 2.8 & 11.1 & 2.8 \\
\hline
\end{tabular}




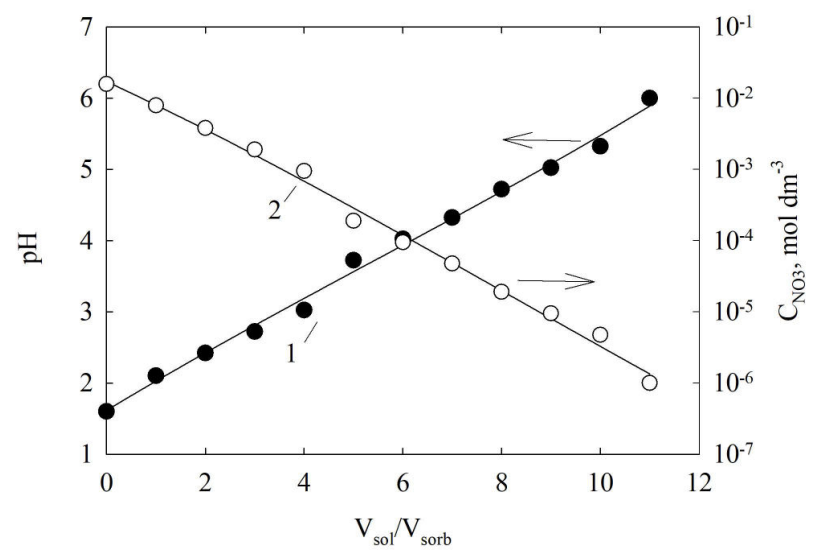

Fig. 4. The $\mathrm{pH}$ of the solution at the outlet of column (1) and the concentration of $\mathrm{NO}_{3}{ }^{-}$ions in it (2) as a function of the ratio of water to sorbent

of the solution reached $0.04 \mathrm{~mol} \cdot \mathrm{dm}^{-3}$. After passing the fivefold volume of water, the concentration of $\mathrm{NO}_{3}{ }^{-}$ions was $0.3 \mathrm{mmol} \cdot \mathrm{dm}^{-3}\left(18 \mathrm{mg} \cdot \mathrm{dm}^{-3}\right)$. This is well below the maximum permissible concentration even for tap water. Thus, the first portion of the solution, which is formed during washing, can be used to prepare a solution for regeneration.

Commonly, the processing of liquid lithiumcontaining concentrates includes lithium precipitation as carbonate. Since acidic solution is used in sorbent regeneration, it is recommended to pre-neutralize it with gaseous ammonia to prevent an increase in concentrate volume. Its introduction into ion concentrate will increase the nitrogen content of the liquid waste that is generated during processing. As shown in Table 3, neutralization will not lead to the formation of sediment: the content of mineral components in the concentrate is lower than their solubility at $20^{\circ} \mathrm{C}$.

Preliminary analysis of the background data and experimental studies showed that reducing the amount of solvent by 40 times (i.e. by $97.2 \%$ ) is optimal when concentrating saline solution: nitrates are not precipitated and the formation of sediments of potassium, sodium and ammonium carbonates is minimized. Under industrial conditions, it is advisable to use solar evaporation to concentrate the solution.

It is recommended to use a saturated solution of $\mathrm{K}_{2} \mathrm{CO}_{3}(8 \mathrm{M})$ to precipitate $\mathrm{Li}_{2} \mathrm{CO}_{3}$ from the nitrate solution, since it contains potassium - a nutrient for crops. The use of a saturated solution is necessary to inhibit the hydrolysis of carbonates, which leads to their conversion into hydrocarbonates. It should be noted that, unlike carbonate, $\mathrm{LiHCO}_{3}$ is well soluble in water.

Calculation of the lithium carbonate loss due to its solubility in water at $20^{\circ} \mathrm{C}$ (its solubility product under these conditions is 0.002 ):

$\mathrm{K}_{\mathrm{s}}=\left[2 \mathrm{Li}^{+}\right]^{2}\left[\mathrm{CO}_{3}{ }^{2-}\right]$

where the square brackets correspond to equilibrium concentrations.

At a ratio of concentrate to precipitate volumes of $1: 1$, the concentration of $\mathrm{CO}_{3}{ }^{2-}$ anions is $4 \mathrm{~mol} \cdot \mathrm{dm}^{-3}$. Consequently, the lithium content in the carbonate solution is $0.011 \mathrm{~mol} \cdot \mathrm{dm}^{-3}$; the solubility is 0.083 per $100 \mathrm{~g}$ of water in terms of $\mathrm{Li}_{2} \mathrm{CO}_{3}$. Thus, the presence of a large excess of $\mathrm{CO}_{3}{ }^{2-}$ anions leads to a significant decrease in the solubility

Table 3

Processing of salt concentrate after sorbent regeneration (initial content)

\begin{tabular}{|c|c|c|c|c|c|}
\hline & Salt characteristics & $\mathrm{Li}^{+}$ & $\mathrm{Na}^{+}$ & $\mathrm{K}^{+}$ & $\mathrm{NH}_{4}^{+}$ \\
\hline \multicolumn{6}{|c|}{ Salt concentrations after seven cycles of sorbent regeneration } \\
\hline \multirow{10}{*}{ Nitrates } & molecular weight & 69 & 85 & 101 & 80 \\
\hline & solubility, g per $100 \mathrm{~g}$ of water $\left(20^{\circ} \mathrm{C}\right)$ & 70 & 87.6 & 31.6 & 212 \\
\hline & salt content, $\mathrm{M}$ & 0.020 & 0.074 & 0.019 & \\
\hline & salt content, g per $100 \mathrm{~g}$ of water & 0.138 & 0.629 & 0.192 & \\
\hline & \multicolumn{5}{|c|}{ Neutralization with ammonia (formation of nitrates of alkali metals and ammonia) } \\
\hline & salt content, $\mathrm{M}$ & 0.020 & 0.074 & 0.019 & 0.4 \\
\hline & salt content, g per $100 \mathrm{~g}$ of water & 0.138 & 0.629 & 0.192 & 3.2 \\
\hline & \multicolumn{5}{|c|}{ Solvent removal (concentration by 40 times) } \\
\hline & salt content, $\mathrm{M}$ & 0.8 & 2.96 & 0.76 & 16 \\
\hline & salt content, g per $100 \mathrm{~g}$ of water & 5.52 & 25.16 & 7.68 & 128 \\
\hline \multirow{5}{*}{ Carbonates } & \multicolumn{5}{|c|}{ Precipitation by saturated $\mathrm{K}_{2} \mathrm{CO}_{3}$ solution (volume ration of salt concentrate and precipitant is $1: 1$ ) } \\
\hline & molecular weight & 74 & 106 & 138 & 79 \\
\hline & solubility, g per $100 \mathrm{~g}$ of water $\left(20^{\circ} \mathrm{C}\right)$ & 0.72 & 44.7 & 155.8 & decomposes \\
\hline & salt content, $\mathrm{M}$ & 0.4 & 1.48 & 4.38 & 8 \\
\hline & salt content, g per $100 \mathrm{~g}$ of water & 2.96 & 15.69 & 60.44 & 63.20 \\
\hline
\end{tabular}


of the precipitate. It is advisable to use hot water for washing the precipitate, since the solubility of potassium and sodium carbonates increases with increasing temperature and the ammonium carbonate decomposes at $60^{\circ} \mathrm{C}$.

To test the proposed approach, the eluate $\left(\sim 1 \mathrm{dm}^{3}\right)$ was neutralized by passing of $\mathrm{NH}_{3}$, evaporated to $25 \mathrm{~cm}^{3}$ and precipitated by hot saturated $\mathrm{K}_{2} \mathrm{CO}_{3}$ solution at temperature close to $100^{\circ} \mathrm{C}$. Then, the precipitate was washed with hot water. The resulting product $(90 \%$ yield) contained $98 \%$ of the basic substance, thereby exhibiting analytically pure qualification.

After separation of the precipitate, the stock solution was evaporated by heating in water bath. The precipitate contained nitrates and carbonates in a molar ratio of $5: 1$, the ratio of $\mathrm{K}$ to $\mathrm{Na}$ was $3: 1$. This product can be used as a mineral fertilizer for acid soils.

From an economic point of view, it seems advantageous to integrate the sorption method of extracting $\mathrm{Li}^{+}$ions into the seawater desalination scheme by reverse osmosis. These steps include the removal of large particles from water by basic filter and the removal of organic impurities by activated carbon. In case of desalination, the water is further supplied to the reverse osmosis plants. However, preremoval of hardness ions is recommended for sorption removal of $\mathrm{Li}^{+}$ions as they have a negative effect on sorption. Thus, the sorption capacity is $0.026 \mathrm{mmol} \cdot \mathrm{g}^{-1}$ in the presence of $\mathrm{Ca}^{2+}$ and $\mathrm{Mg}^{2+}$ ions in the solution [10], whereas it is $0.06 \mathrm{mmol} \cdot \mathrm{g}^{-1}$ in the absence of these. Nanofiltration can be used to soften the water with the use of phosphorous-free antiscalant to prevent sedimentation on the membrane.

Consequently, after preliminary purification, some of the seawater is fed to a reverse osmosis plant for complete desalination and part of it is directed to the nanofiltration unit (Fig. 5). The next step is the sorption extraction of $\mathrm{Li}^{+}$ions, which lasts until the sorbent is saturated. In this case, the complete removal of lithium from water is not important, since the content of this component in water is not regulated. To wash the sorbent after regeneration, it is possible to use water desalinated with reverse osmosis (the same water can also be used to prepare the $\mathrm{K}_{2} \mathrm{CO}_{3}$ solution). Upon washing, an acidic solution is formed in the column, the first portions of which can be used to prepare the $\mathrm{HNO}_{3}$ solution and the subsequent portions can be added to the nanofiltration permeate, which can be used for technical purposes.

After neutralization and solar evaporation of the spent regenerating solution, it is possible to obtain

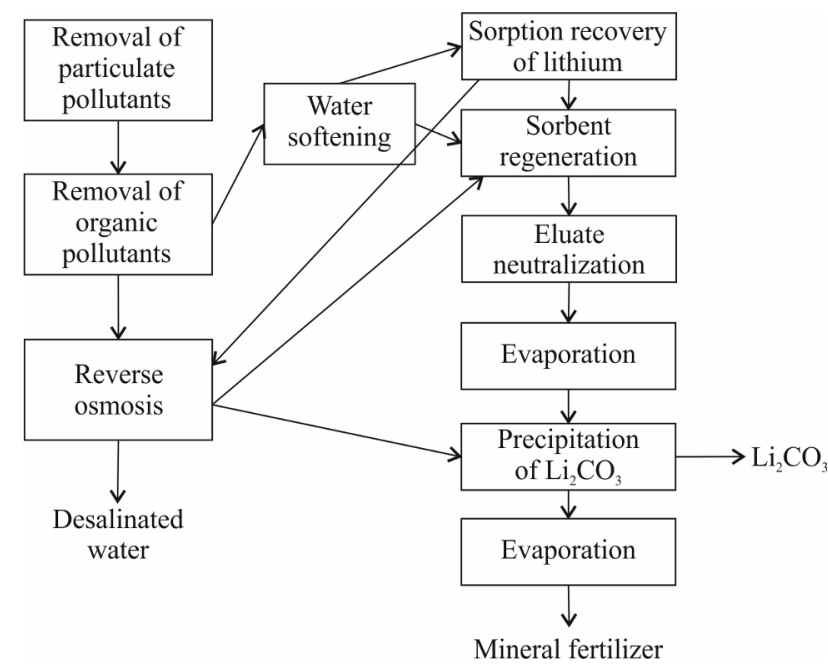

Fig. 5. Integration of lithium sorption extraction into seawater desalination process

a salt concentrate from which lithium carbonate is precipitated. It is recommended to use desalinated water for washing. Evaporation of the mother liquor allows obtaining a complex nitrogen-potassium mineral fertilizer for acidic soils.

\section{Conclusions}

For the sorption recovery of lithium from seawater, it is recommended to use titaniummanganese sorbent, which is characterized by a high content of Li-selective phase. The $\mathrm{TiO}_{2}$ phase acts as a binder: the large size of the granules allows the sorbent to be used as a filler for sorption columns. The advantage of this material over titanium dioxide is its high sorption capacity and selectivity for $\mathrm{Li}^{+}$ ions. It is recommended to use $1 \mathrm{M} \mathrm{HNO}_{3}$ solution for desorption at a volume ratio of sorbent to solution of 1:5. Almost complete desorption is achieved under these conditions without dissolving the sorbent when the alkali metal ions content is $\sim 0.1 \mathrm{~mol} \cdot \mathrm{dm}^{-3}$ in the eluate. The ratio of concentrations of $\mathrm{Li}^{+}, \mathrm{Na}^{+}$and $\mathrm{K}^{+}$in the concentrate is $1: 4: 1$ after the fifth cycle of sorption-desorption. The processing of concentrate involves bubbling ammonia through a solution, precipitation of $\mathrm{Li}_{2} \mathrm{CO}_{3}$ and obtaining a mixture of nitrates and carbonates of potassium and sodium that can be used as a fertilizer. Lithium carbonate can be a by-product of water desalination: lithium removal can occur after pre-removal of hardness ions by nanofiltration. Water passed through a layer of ion exchanger can be used for technical purposes. Other by-product is a mineral fertilizer containing potassium and sodium nitrate. This by-product was obtained by evaporation of the solution after $\mathrm{Li}_{2} \mathrm{CO}_{3}$ precipitation. Heating was applied to evaporation. Solar evaporation would give a possibility to obtain 
the fertilizer containing also ammonia carbonate.

\section{REFERENCES}

1. Lithium and lithium compounds / Kamienski C.W., McDonald D.P., Stark M.W, Papcun J.R. // Kirk-Othmer Encyclopedia of Chemical Technology. - 2004. - Vol.15. - P.1-40.

2. Korthauer $R$. Lithium-ion batteries: basics and applications. Berlin: Springer-Verlag, 2018. - 413 p.

3. Lithium market research - global supply, future demand and price development / Martin G., Rentsch L., Hock M., Bertau M. // Energy Storage Mater. - 2017. - Vol.6. - P.171-179.

4. Wanger T.C. The Lithium future - resources, recycling, and the environment // Conserv. Lett. - 2011. - Vol.4. - No. 3. - P.202-206.

5. Swain B. Separation and purification of lithium by solvent extraction and supported liquid membrane, analysis of their mechanism: a review // J. Chem. Technol. Biotechnol. - 2016. - Vol.91. - No. 10. - P. 2549-2562.

6. Lithium and lithium isotope profiles through the upper oceanic crust: a study of seawater-basalt exchange at ODP Sites 504B and 896A / Chan L.H., Alt J.C., Teagle D.A.H. // Earth Planet. Sci. Lett. - 2002. - Vol.201. - No. 1. - P.187-201.

7. Recovery of lithium in seawater using a titanium intercalated lithium manganese oxide composite / Ryu T., Shin J., Ghoreishian S.M., Chung K.S., Huh Y.S. // Hydrometallurgy. - 2019. - Vol.184. - P.22-28.

8. Recovery of lithium ions from seawater using a continuous flow adsorption column packed with granulated chitosan-lithium manganese oxide / Ryu T., Haldorai Y., Rengaraj A., Shin J., Hong H.J., Lee G.W., Han Y.K., Huh Y.S., Chung K.S. // Ind. Eng. Chem. Res. - 2016. - Vol.55. - No. 26. - P.7218-7225.

9. Structural characteristics and sorption properties of lithium-selective composite materials based on $\mathrm{TiO}_{2}$ and $\mathrm{MnO}_{2}$ / Chaban M.O., Rozhdestvenska L.M., Palchyk O.V., Dzyazko Y.S., Dzyazko O.G. // Appl. Nanosci. - 2019. - Vol.9. - P.1037-1045.

10. Chaban M.O., Rozhdestvenska L.M., Dzyazko Y.S. Electromembrane recovery of $\mathrm{Li}^{+}$ions from aqueous solutions using a sorbent based on $\mathrm{TiO}_{2} \cdot \mathrm{MnO}_{2} / /$ Voprosy Khimii $\mathrm{i}$ Khimicheskoi Tekhnologii. - 2019. - No. 2. - P.135-143.

11. Organic-inorganic membranes for filtration of corn distillery / Myronchuk V.G., Dzyazko Yu.S., Zmievskii Yu.G., Ukrainets A.I., Bildukevich A.V., Kornienko L.V., Rozhdestvenskaya L.M., Palchik A.V. // Acta Periodica Technologica. - 2016. - Vol.2016. - No. 47. - P.153-165.
12. Ion-exchange resin modified with aggregated nanoparticles of zirconium hydrophosphate. Morphology and functional properties / Dzyazko Yu.S., Ponomaryova L.N., Volfkovich Yu.M., Trachevskii V.V., Palchik A.V. // Microporous Mesoporous Mater. - 2014. - Vol.198. - P.55-62.

13. Jiang $J$. Synthesis and research of lithium manganese titanium oxide // Adv. Mater. Res. - 2012. - Vol.549. - P.466-469.

14. Composition and structure of acid leached $\mathrm{LiMn}_{2-\mathrm{y}} \mathrm{Ti}_{\mathrm{y}} \mathrm{O}_{4}$ $(0.2 \leq y \leq 1.5)$ spinels / Avdeev G., Amarilla J.M., Rojo J.M., Petrov K., Rojas R.M. // J. Solid State Chem. - 2009. - Vol.182. - P.3226-3231

15. Inorganic and polymer modified sorbents: removal of uranium(VI) from aqueous solutions and regeneration / Perlova O.V., Dzyazko Yu.S., Ivanova I.S., Malinovska O.O. // Voprosy Khimii i Khimicheskoi Tekhnologii. - 2018. - No. 6. - P.125-132.

Received 24.04.2020

\section{СОРБЦЙНЕ ВИЛУЧЕННЯ ІОНІВ $\mathrm{Li}^{+} 3$ БАГАТОКОМПОНЕНТНИХ РОЗЧИНІВ. РЕГЕНЕРАЩЯ СОРБЕНТУ ТА ОБРОБЛЕННЯ КОНЦЕНТРАТУ}

\section{М.О. Чабан, Л.М. Рождественська, О.В. Пальчик}

Робота присвячена розробці сорбційного методу для вилучення літію з морської води з використанням оксидів полівалентних металів, одержсаних у вигляді великих гранул. Початкові оксиди Ті і Ti-Мn містили фазу шпінелі літію, сорбенти попередньо переводили у форму водню. Сорбція $\mathrm{Li}^{+}$в динамічних умовах досліджувалася з модельного розчину, що містить

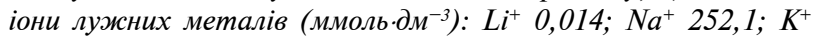
5,4. Було виявлено, що співвідношення вмісту $\mathrm{Li}^{+}, \mathrm{Na}^{+} \mathrm{ma} \mathrm{K}^{+} \mathrm{y}$ сорбентах становить 1:11:1 ( $\mathrm{TiO}_{2}$ ) та 1:4:1 ( $\left.\mathrm{Ti}-\mathrm{Mn}\right)$. Ці сорбенти можна частково регенерувати розчином $\mathrm{NaOH}$ та повністю - кислотами; вони не розчиняються в $1 \mathrm{M}$ розчині $\mathrm{HNO}_{3}$ при $20-45^{\circ}$ С. Крім того, вивчено вплив кількості сорбенту та концентрації розчину $\mathrm{HNO}_{3}$ на десорбцію іонів $\mathrm{Li}^{+}$. Для сорбенту на основі титан-мангану було здійснено кілька ииклів сорбції-десорбції без оновлення регенеруючого розчину. Показано, що сорбційна здатність залишається сталою протягом 5 ииклів, потім зменшується та відновлюється при застосуванні «свіжого» регенеруючого розчину. Перероблення концентрату передбачає барботування аміаку через розчин, осадження $\mathrm{LiCO}_{3}$ та одержання суміші нітратів та карбонатів калію та натрію, які можна використовувати як добриво. Запропоновано інтегрувати вилучення літію у процес зворотно-осмотичного опріснення морської води: сорбційний процес передбачає їі попередне пом'якшення.

Ключові слова: літій, титано-марганцева шпінель, знесолення морської води, сорбція, регенерація сорбенту. 


\section{SORPTION REMOVAL OF $\mathrm{Li}^{+}$IONS FROM MULTICOMPONENT SOLUTIONS. REGENERATION OF SORBENT AND PROCESSING OF CONCENTRATE}

\section{M.O. Chaban ", L.M. Rozhdestvenska, O.V. Palchik}

V.I. Vernadsky Institute of General and Inorganic Chemistry of the National Academy of Sciences of Ukraine, Kyiv, Ukraine

* e-mail: mary.chaban@gmail.com

The work is devoted to the development of a sorption method for the extraction of lithium from seawater using oxides of polyvalent metals obtained in the form of large granules. The initial oxides of Ti and Ti-Mn contained a phase of lithium spinel, the sorbents were previously converted into hydrogen form. Sorption of $\mathrm{Li}^{+}$ions under dynamic conditions was investigated using a model solution containing the following alkali metal ions $\left(\mathrm{mmol} \cdot \mathrm{dm}^{-3}\right): \mathrm{Li}^{+}$0.014, $\mathrm{Na}^{+} 252.1$, and $\mathrm{K}^{+}$5.4. The ratio of $\mathrm{Li}^{+}, \mathrm{Na}^{+}$and $\mathrm{K}^{+}$contents in the sorbents was found to be 1:11:1 ( $\mathrm{in}^{\mathrm{TiO}} \mathrm{O}_{2}$ ) and 1:4:1 (in $\mathrm{Ti}-\mathrm{Mn}$ ), respectively. These sorbents could be regenerated by $\mathrm{NaOH}$ solution (partially) or by acids (completely); they did not dissolve in $1 \mathrm{M}$ $\mathrm{HNO}_{3}$ at $20-45^{\circ} \mathrm{C}$. The effects of sorbent dosage and concentration of $\mathrm{HNO}_{3}$ solution on desorption of $\mathrm{Li}^{+}$ions were studied. Several cycles of sorption-desorption were carried out for titanium-manganese sorbent without renewal of the regenerating solution. It was shown that the sorption capacity remains constant for 5 cycles; then it is decreased and can be recovered by using a fresh regenerating solution. The treatment of the obtained concentrate involves bubbling ammonia through the solution, precipitation of $\mathrm{LiCO}_{3}$ and formation of a mixture of nitrates and carbonates of potassium and sodium that can be further used as fertilizer. It is proposed to integrate the lithium extraction into the reverse osmotic desalination of seawater: the sorption process implies its preliminary softening.

Keywords: lithium; titanium-manganese spinel; seawater desalination; sorption; sorbent regeneration.

\section{REFERENCES}

1. Kamienski C.W., McDonald D.P., Stark M.W, Papcun J.R., Lithium and lithium compounds. In: Kirk-Othmer Encyclopedia of Chemical Technology, 2004.

2. Korthauer R., Lithium-ion batteries: basics and applications. Springer-Verlag, Berlin, 2018. 413 p.

3. Martin G., Rentsch L., Hock M., Bertau M. Lithium market research - global supply, future demand and price development. Energy Storage Materials, 2017, vol. 6, pp. 171179.

4. Wanger T.C. The Lithium future-resources, recycling, and the environment. Conservation Letters, 2011, vol. 4, pp. 202-206.

5. Swain B. Separation and purification of lithium by solvent extraction and supported liquid membrane, analysis of their mechanism: a review. Journal of Chemical Technology \& Biotechnology, 2016, vol. 91, pp. 2549-2562.

6. Chan L.H., Alt J.C., Teagle D.A.H. Lithium and lithium isotope profiles through the upper oceanic crust: a study of seawater-basalt exchange at ODP Sites 504B and 896A. Earth and Planetary Science Letters, 2002, vol. 201, pp. 187-201.
7. Ryu T., Shin J., Ghoreishian S.M., Chung K.S., Huh Y.S. Recovery of lithium in seawater using a titanium intercalated lithium manganese oxide composite. Hydrometallurgy, 2019 , vol. 184, pp. 22-28.

8. Ryu T., Haldorai Y., Rengaraj A., Shin J., Hong H.J., Lee G.W., Han Y.K., Huh Y.S., Chung K.S. Recovery of lithium ions from seawater using a continuous flow adsorption column packed with granulated chitosan-lithium manganese oxide. Industrial \& Engineering Chemistry Research, 2016, vol. 55, pp. $7218-7225$.

9. Chaban M.O., Rozhdestvenska L.M., Palchyk O.V., Dzyazko Y.S., Dzyazko O.G. Structural characteristics and sorption properties of lithium-selective composite materials based on $\mathrm{TiO}_{2}$ and $\mathrm{MnO}_{2}$. Applied Nanoscience, 2019, vol. 9, pp. 1037-1045.

10. Chaban M.O., Rozhdestvenska L.M., Dzyazko Y.S. Elektromembranne vyluchennya ioniv $\mathrm{Li}^{+} \mathrm{z}$ vodnykh rozchyniv iz vykorystannyam sorbentu na osnovi $\mathrm{TiO}_{2} \cdot \mathrm{MnO}_{2}$ [Electromembrane recovery of $\mathrm{Li}^{+}$ions from aqueous solutions using a sorbent based on $\mathrm{TiO}_{2} \cdot \mathrm{MnO}_{2}$. Voprosy Khimii $i$ Khimicheskoi Tekhnologii, 2019, no. 2, pp. 135-143. (in Ukrainian).

11. Myronchuk V.G., Dzyazko Yu.S., Zmievskii Yu.G., Ukrainets A.I., Bildukevich A.V., Kornienko L.V., Rozhdestvenskaya L.M., Palchik A.V. Organic-inorganic membranes for filtration of corn distillery. Acta Periodica Technologica, 2016, vol. 2016, no. 47, pp. 153-165.

12. Dzyazko Yu.S., Ponomaryova L.N., Volfkovich Yu.M., Trachevskii V.V., Palchik A.V. Ion-exchange resin modified with aggregated nanoparticles of zirconium hydrophosphate. Morphology and functional properties. Microporous and Mesoporous Materials, 2014, vol. 198, pp. 55-62.

13. Jiang J.H. Synthesis and research of lithium manganese titanium oxide. Advanced Materials Research, 2012, vol. 549, pp. 466-469.

14. Avdeev G., Amarilla J.M., Rojo J.M., Petrov K., Rojas R.M. Composition and structure of acid leached $\mathrm{LiMn}_{2-\mathrm{y}} \mathrm{Ti}_{\mathrm{y}} \mathrm{O}_{4}(0.2 \leq \mathrm{y} \leq 1.5)$ spinels. Journal of Solid State Chemistry, 2009, vol. 182, pp. 3226-3231.

15. Perlova O.V., Dzyazko Yu.S., Ivanova I.S., Malinovska O.O., Palchik A.V. Neorganichni ta polimerni modyfikovani sorbenty: vyluchenn'ya uranu(VI) z vodnykh rozchyniv ta regeneratsiya [Inorganic and polymer modified sorbents: removal of uranium(VI) from aqueous solutions and regeneration]. Voprosy Khimii i Khimicheskoi Tekhnologii, 2018, no. 6, pp. 125-132. (in Ukrainian). 